\title{
Research Article \\ Impact of integrated weed management practices soil microbial count and grain yield in black gram (Phaseolus
} mungo L.)

\author{
J. P. Bholane, Kavita D. Rajput and V.M. Bhale
}

\begin{abstract}
SUMMARY
A field investigation was carried out during Kharif season in 2010 at Agronomy Department Farm, Dr.Panjabrao Deshmukh Krishi Vidyapeeth, Akola, to evaluate the effect of four herbicides (imazethapyr, pendimethalin, fenoxyprop-p-ethyl and quizalofop -p-ethyl ) applied at different rates with different time of application (pre-emergence,post emergence and combination of both) and cultural practices on soil microflora and yield of black gram (Phaseolus mungo). Data revealed that different chemicals and cultural weed control practices were exhibited their superiority over weedy check and reduced the crop weed competition by controlling the annual and broad leaved weeds. Among all the weed control treatments, pre-emergence application of pendimethalin @ $1.5 \mathrm{~kg} /$ ha showed higher yield per ha (10.05) and in case of in microbial study, bacterial, fungal and actinomycetes count before spraying of herbicide was non-significant but microbial count was reduced after spraying of herbicides as compared to before spraying of herbicides, as a result(before and after spraying of herbicide) pre-emergence application of imazethapyr at $75 \mathrm{~g} \mathrm{ha}^{-1}[(25.11,17.10),(19.50,10.84)$ and $(22.30$ ,16.10)] showed the lower microbial count. In case of weedy check(26.90, 20.60 and 23.98) showed maximum microbial count followed by weed free (26.50, 20.30 and 22.60$)$, among all the weed control practices.
\end{abstract}

Key Words : Yield, Cultural methods, Herbicidal practices, Soil microflora

How to cite this article : Bholane, J.P., Rajput, Kavita D. and Bhale, V.M. (2021). Impact of integrated weed management practices soil microbial count and grain yield in black gram (Phaseolus mungo L.).Internat. J. Plant Sci., 16 (AAEBSSD): 43-45, DOI: 10.15740/ HAS/IJPS/16.AAEBSSD/43-45, Copyright@ 2021: Hind Agri-Horticultural Society.

Article chronicle : Received : 09.07.2021; Revised : 12.07.2021; Accepted : 19.07.2021

\section{MEMBERS OF THE RESEARCH FORUM}

Author to be contacted :

J.P. Bholane, Dr. Panjabrao Deshmukh Krishi Vidyapeeth, Akola (M.S.) India

Email : jayubholane@gmail.com

Address of the Co-authors:

Kavita D. Rajput and V.M. Bhale, Dr. Panjabrao Deshmukh Krishi Vidyapeeth, Akola (M.S.) India
B lack gram (Phaseolus mungo) is one of the important pulse crop grown in the rainfed farming system through out the India.It is the second most important pulse crop covering $31,00,000$ ha ( 16.28 $\%$ ) area in the country .It has high nutritive value and consist high content of proteins, vitamins and minerals. During Kharif (monsoon) season the weeds emerge 
along with the crop due to favourable environment condition and the crop suffers heavy loss from unchecked weeds particularly in the initial stage of its growth (Vats and Sawhney,1981). In the later stage, however, the black gram offers good competition (Ali et al., 1982). Overall effect is that the weeds caused grain yield losses upto $50 \%$ or even more (Sharma and Nayital, 1991). The conventional method of weed control through cultural practices i.e. Hand weeding, Hoeing is not only too expensive but at times it is not feasible due to wet soil conditions prevailing during rainy season. So, the use of new selective herbicides (pendimethalin, fenoxyprop-pethyl,Imazethapyr and quizalofop-p-ehtyl) with cultural practices in legumes can be effective and economical for controlling the broad spectrum of annual grassy and broad leaf weeds (Yadav et al.,1983). Apart from growth and yield attributes, the nature of yield response to weed management determines the feasibility of adoption of the technology by growers. With this objectives, the present study was under taken to evaluate the effect of weed practices on microbial count and enhance the yield of black gram by controlling annual and broad leaved weeds and reduced the crop weed competition through different chemical and cultural weed control practices.

\section{MATERIAL AND METHODS}

Experiment was carried out on clay loam and slightly alkaline soil with low in nitrogen, medium in organic carbon and phosphorus and high in potassium during Kharif season of 2010-11 at Agronomy Farm, Department of Agronomy, Dr. PDKV, Akola. Thirteen treatments consisting different cultural and herbicidal combinations replicated thrice in randomized block design. Black gram (var. TAU-1) was sown with $30 \times 10 \mathrm{~cm}$ spacing and fertilizer was applied @ 20:40:00 NPK kg/ ha through urea and diammonium phosphate. For soil microflora study, serial dilution plate technique was used for isolation and enumeriation of soil bacteria, fungi and actinomycetes as described by Dhingra and Sinclair (1993). Also data on grain yield was recorded after harvest.

\section{RESULTS AND DISCUSSION}

The results obtained from the present investigation as well as relevant discussion have been summarized under following heads :

\section{Microbial count:}

Before spraying of herbicide treatments difference for microbial count (bacterial, fungal and actinomycetes)

\begin{tabular}{|c|c|c|c|c|c|c|c|}
\hline \multirow{2}{*}{ Treatments } & \multicolumn{2}{|c|}{$\begin{array}{c}\text { Bacterial count } \\
\left(\times 10^{7} \mathrm{cfu} / \mathrm{g} \text { soil }\right) \\
\end{array}$} & \multicolumn{2}{|c|}{$\begin{array}{c}\text { Fungal count } \\
\left(\mathrm{x} 10^{4} \mathrm{cfu} / \mathrm{g} \text { soil }\right)\end{array}$} & \multicolumn{2}{|c|}{$\begin{array}{c}\text { Actinomycetes count } \\
\left(\mathrm{x} 10^{6} \mathrm{cfu} / \mathrm{g} \text { soil }\right)\end{array}$} & \multirow{2}{*}{$\begin{array}{l}\text { Grain } \\
\text { yield } \\
(\mathrm{q} / \mathrm{ha})\end{array}$} \\
\hline & $\begin{array}{c}\text { Before } \\
\text { spraying }\end{array}$ & $\begin{array}{c}\text { After } \\
\text { spraying }\end{array}$ & $\begin{array}{c}\text { Before } \\
\text { spraying }\end{array}$ & $\begin{array}{c}\text { After } \\
\text { spraying }\end{array}$ & $\begin{array}{c}\text { Before } \\
\text { spraying }\end{array}$ & $\begin{array}{c}\text { After } \\
\text { spraying }\end{array}$ & \\
\hline $\mathrm{T}_{1}-$ Weed free & 26.50 & - & 20.30 & - & 22.60 & - & 12.67 \\
\hline $\mathrm{T}_{2}$ - Weedy check & 26.90 & - & 20.60 & - & 23.98 & - & 5.14 \\
\hline $\mathrm{T}_{3}-2$ Hand weeding (15 fb $\left.30 \mathrm{DAS}\right)$ & 26.44 & - & 20.20 & - & 23.50 & - & 9.31 \\
\hline $\mathrm{T}_{4}-2$ Hoeing (10 fb 20 DAS) & 25.95 & - & 19.80 & - & 22.10 & - & 6.81 \\
\hline $\mathrm{T}_{5}$ - Imazethapyr @ $50 \mathrm{~g} \mathrm{ha}^{-1} \mathrm{PE}$ (At sowing) & 26.33 & 18.00 & 19.98 & 12.35 & 23.35 & 18.30 & 6.11 \\
\hline $\mathrm{T}_{6}$ - Imazethapyr @ $75 \mathrm{~g} \mathrm{ha}^{-1} \mathrm{PE}$ (At sowing) & 25.11 & 17.10 & 19.50 & 10.84 & 22.30 & 16.10 & 8.28 \\
\hline $\mathrm{T}_{7}$ - Pendimethalin@1000 $\mathrm{g} \mathrm{ha}^{-1} \mathrm{PE}$ (At sowing) & 26.00 & 21.63 & 20.00 & 15.36 & 23.31 & 20.40 & 9.97 \\
\hline $\mathrm{T}_{8}$ - Pendimethalin@1500 g ha ${ }^{-1} \mathrm{PE}$ (At sowing) & 26.86 & 19.52 & 20.50 & 13.11 & 23.80 & 19.33 & 10.05 \\
\hline T9 - Fenoxyprop-p-ethyl @ 100 g ha $^{-1}$ POE (15 DAS) & 26.35 & 22.73 & 20.10 & 17.20 & 23.40 & 20.92 & 8.83 \\
\hline $\mathrm{T}_{10}$ - Fenox yprop-p-ethyl @ $125 \mathrm{~g} \mathrm{ha}^{-1}$ POE (15 DAS) & 25.30 & 20.16 & 19.40 & 16.00 & 23.11 & 20.60 & 9.86 \\
\hline $\mathrm{T}_{11}$ - Quizalofop-p-ethyl @ $50 \mathrm{~g} \mathrm{ha}^{-1}$ POE (15 DAS) & 26.10 & 23.54 & 20.05 & 17.80 & 22.80 & 21.20 & 7.78 \\
\hline $\mathrm{T}_{12}$ - Quizalofop-p-ethyl @ $75 \mathrm{~g} \mathrm{ha}^{-1} \mathrm{POE}$ (15 DAS) & 25.15 & 22.99 & 19.20 & 16.99 & 22.00 & 20.98 & 8.55 \\
\hline $\begin{array}{l}\mathrm{T}_{13} \text { - Imazethapyr @ } 50 \mathrm{~g} \mathrm{ha}^{-1} \text { PE fb Quizalofop-p-ethyl } \\
\text { @ } 50 \mathrm{~g} \mathrm{ha}^{-1} \mathrm{POE} \text { (At sowing fb } 15 \text { DAS) }\end{array}$ & 26.20 & 21.16 & 20.00 & 15.60 & 22.98 & 19.84 & 8.22 \\
\hline $\mathrm{SE}(\mathrm{m}) \pm$ & 1.86 & 1.23 & 1.06 & 0.84 & 2.05 & 0.98 & 0.86 \\
\hline C.D. at $5 \%$ & - & 3.59 & - & 2.44 & - & 2.86 & 2.52 \\
\hline G.M. & 26.09 & 14.37 & 19.97 & 10.40 & 23.02 & 13.67 & 3.49 \\
\hline
\end{tabular}


was non-significant. But after spraying of herbicide, the bacterial count was reduced in all herbicidal treatments over all the cultural methods of weed control except weed free, which showed highest microbial count over all the treatments. Similar trend was observed in case of fungal and actinomycetes count. Bacterial count was more than actinomycetes and fungal count which showed that herbicide had no toxic effect on total bacterial count in rhizospheric soil and microorganisms are able to degrade some herbicides and utilize them as a source of biogenic elements. Similar findings were observed by Araujo et al. (2003) and Barman (2008). As such the adverse effects of field applied herbicides on the population of soil microbes are usually limited to 2-3 days then recover to normal levels. Similar findings were observed by Nalayini and Sankaran (1992) and Sahid (1992).

\section{Grain yield:}

Weed management practices significantly improved the grain yield over weedy check. Uncontrolled weeds on an average reduced black gram yield by $45 \%$. Weed free treatment recorded significantly highest $(12.67 \mathrm{Q} /$ ha) grain yield among all the treatments and weedy check treatment recorded significantly lowest $(5.14 \mathrm{q} / \mathrm{ha})$ grain yield than rest of the weed control treatments (Table 1). Similar results were recorded by Sharma et al. (1988). In herbicidal treatments, pre-emergence application of pendimethalin@1.5kg/ha recorded maximum (10.05 q / ha) yield among rest of the herbicidal treatments followed by PE application of pendimethalin@ $1.0 \mathrm{~kg} / \mathrm{h}$ a recorded $(9.97 \mathrm{q} / \mathrm{ha})$ grain yield and remaining herbicidal treatments bring at par with each other. This treatments controlled the weeds efficiently and thus resulted in significant increased in grain yield. Pre-emergence application of pendimethalin at $1.5 \mathrm{~kg} / \mathrm{ha}$ and $1.0 \mathrm{~kg} / \mathrm{ha}$ gave significantly higher seed yield of black gram as compared to weedy check, Imazethapyr, quizalofop-pethyl and fenoxyprop-p-ethyl. Above results are in accordance with the findings of Malliswari et al. (2008) and Mishra and Bhanu (2006).

\section{Conclusion:}

It was concluded that the Microbial count was reduced after spraying of herbicides as compared to before spraying of herbicides and it was observed that the (before and after spraying of herbicide) pre- emergence application of imazethapyr at $75 \mathrm{~g} \mathrm{ha}^{-1}[(25.11$, $17.10),(19.50,10.84)$ and $(22.30,16.10)]$ showed the lower microbial count compare to weedy check and among all the weed control treatments, pre-emergence application of pendimethalin@1.5 kg/ha showed higher yield per ha (10.05) and superior over the weedy check.

\section{REFERENCES}

Ali, M., Pandey, R.K. and Rawat, C.R. (1982). Studies on intercropping and weed management in piqeonpea under dryland conditions. Madras. J. Agric. Sci., 69 :474-478.

Araujo, A. S. F., Monteriro, R. T. R. and Ab. Arkeli, R. B. (2003). Effect of glyphosate on the microbial activity to brazilin soil. Chemosphere, 52 : 784-799.

Barman, K.K. (2008). Impact of herbicides on soil environment. Indian Journal of Weed Science, 40: 10-17.

Dhingra, O.D. and Sinclair, J.B. (1993). Basic plant pathology method, CBS, Pub. Delhi, pp 174-180.

Malliswari, T., Reddy, M. P., Sagar, K.G. and Chandrika, V. (2008). Effect of irrigation on weed management practices on weed control and yield of blackgram. Indian J. Weed Sci., 40(1\&2) : 85-86.

Mishra, J. S. and Bhanu, C. (2006). Effect of herbicides on weeds, nodulation and growth of rhizobium in summer blackgram. Indian J. Weed Sci.,38(1\&2) : 150153.

Nalayini, P. and Sankaran, S. (1992). Effect of pre-emergence herbicides on soil microorganisms. Indian J. Agron., 37 (3) : 625-626.

Sahid, I. (1992). Effects of paraquat and alachlor on soil microorganisms in peat soil. Weed Abs., 42(11): 562.

Sharma, J. and Nayital, S. C. (1991). Crop-weed competition in maize+black gram intercropping system. Indian J. Agronomy, 36: 64-67.

Sharma, K.K. and Rajkhowa, D.J. (1988). Performance of herbicides for weed control in black gram. Pesticides, 22 (6): 39.

Vats, O. P. and Sawhney, J. S. (1981). Crop weed competition studies in black gram. Abstract of papers, Annual Conference of Indian Society of Weed Science, India. 8 .

Yadav, S. K., Singh, S. P. and Bhan, V. M. (1983). Weed control in chickpea. Tropical Pest Management, 29 (3) : 297398.

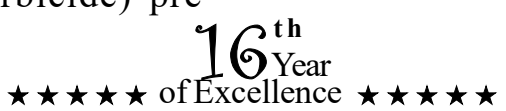

